\title{
Comparison of pigment in automotive solid color paints by FT-IR and XRF spectroscopy for forensic aspect
}

\author{
Ha-Sun Park ${ }^{\star}$, Ki-Wook Kim, Sangcheol Heo, Seung-Jin Ryu, Hyunik Lee and Ji-Sook Min \\ National Forensic Service, Jiyang-ro 139, Yangchon-ku, Seoul 158-707, Korea \\ (Received July 12, 2013; Revised July 29, 2013; Accepted July 29, 2013)
}

\section{법과학적 관점에서 $\mathrm{FT}-\mathrm{IR}$ 과 XRF를 이용한 단색 페인트의 안료 비교 박하선` · 김기욱 · 허상철 · 유승진 · 이현익 · 민지숙 \\ 국립과학수사연구원 \\ (2013. 7. 12. 접수, 2013. 7. 29. 수정, 2013. 7. 29. 승인)}

\begin{abstract}
Identification of paint on victim's clothing and a vehicle are valuable for forensic examination when investigating hit-and-run accidents. Automotive paints on clothes are used to prove a victim caused by traffic accident and to identify a suspected vehicle. The comparison of transferred paints between victim's vehicle and suspected vehicle can be an important evidence in reconstructing the accident situation and in discovering the truth. The paints such as white, yellow, red, blue, or black are hard to examine particle shape under a stereomicroscope because of it is not included aluminum, pearl, and mica flakes in the pigments. The aim of this study under forensic aspect is to compare pigment among basecoat layers of solid paints by identifying inorganic elemental compositions and binder resins of pigments using by micro-FT-IR and micro-XRF spectrometer. The pigment samples were analyzed by using two methods of FT-IR: Reflectance and ATR method. Two methods of FT-IR were useful in discriminating binder resins of pigments by comparing characteristic peaks and patterns of spectra. Also, XRF spectrometer could identify the elemental compositions in inorganic pigments of trace paints which are difficult to compare the identification by FT-IR.

요 약: 교통사고로 인해 피해자 의류 또는 사고관련 차량에 부착된 페인트는 법과학적으로 중요한 증 거물이다. 의류에 부착된 페인트는 용의차량을 추적하고 교통사고의 피해자임을 입증할 수 있는 단서가 되며, 피해차량과 용의차량에 상호 전이되어 부착된 페인트는 페인트의 동일성 비교로써 사고의 진실을 밝히고 사고 상황을 재구성하는데 중요한 역할을 한다. 부착된 페인트는 보통 미량의 시료이고 특히 단 색인 흰색, 노란색, 적색, 청색, 검정색인 경우 페인트 동일성 비교는 입체현미경으로 색상과 안료에 함 유된 알루미늄, 펄, 마이카 등의 입자 형상에 대한 상호 비교가 곤란하므로 이에 대한 분석법이 요구되 었다. 따라서 본 연구의 목적은 단색의 차량 페인트에서 색상을 구현하는 basecoat 층에 대해 micro-FTIR과 micro-XRF를 이용하여 안료의 바인더 수지와 무기안료의 구성원소를 확인하여 법과학적 측면에서 페인트 동일성 비교를 하고자 하였다. FT-IR 분석은 시료를 전처리 없이 Reflectance와 ATR 2가지 방
\end{abstract}

$\star$ Corresponding author

Phone : +82-(0)2-2600-4946 Fax : +82-(0)2-2600-4999

E-mail : sskpark@korea.kr 
법을 병용했으며 Reflectance 스펙트럼은 4000 2000 $\mathrm{cm}^{-1}$ 영역에서 aromatics과 aliphatic, acrylonitrile 등의 피크 정보를 얻었고 ATR 스펙트럼은 2000 650 $\mathrm{cm}^{-1}$ 영역에서 carbonyl, isocyanate, carbamate 등의 피크 및 피크의 패턴 비교로 안료의 바인더 수지를 비교하는데 이용하였다. 또한 XRF 분광법은 미량 페인트의 무기안료에 함유된 구성원소를 확인하여 적외선 흡수스펙트럼으로 동일성 비교가 곤 란한 시료에 대해 판별 가능하게 하였다.

Key words: automotive paint, basecoat, pigment, FT-IR, XRF

\section{1. 서 론}

법과학적 페인트 증거물은 피해차량과 용의차량에 부착된 페인트, 뺑소니 차량에 의한 피해자 의류에 부착된 페인트, 범행현장에서 사용된 도구 페인트, 추락사고에서 피해자의 의류에 부착된 건물 외벽 페 인트, 선박충돌에 의한 페인트 등 다양하다. 특히 뺑 소니 사고에서 피해자 의류에 부착된 페인트와 용의 차량의 페인트, 피해차량과 용의차량에 상호 전이되 어 부착된 페인트에 대한 페인트 동일성 비교의 결과 는 뺑소니 교통사고의 진실을 밝히고 사고 상황을 재 구성하는데 중요한 역할을 하고 있다. 차량 페인트는 표면의 무색투명한 클리어코트(clearcoat), 색상을 부 여하는 베이스코트(basecoat), 은폐효과를 주는 서페 이서(surfacer), 방청효과를 주는 전착도장으로 구성되 어 있지만 의류와 차량에 전이되는 페인트는 보통 클 리어코트 수지와 색상을 부여하는 베이스코트가 미 량으로 전이되어 부착하게 된다. 부착된 페인트의 동 일성은 일차적으로 입체현미경을 이용하여 색상과 형상 검사에 의해 비교하게 되는데 무색투명한 클리 어 수지는 색상의 분별력이 없으므로 베이스코트의 색상 안료 부분을 비교 검사에 이용하게 된다. 베이 스코트의 안료 부분에 대한 일반적인 페인트 색상의 분류는 알루미늄 입자가 함유된 메탈릭 색상(metallic color), 보는 각도에 따라 색상이 달라지는 펄 - 마이카 색상(pearl· mica color), 흰색, 노란색, 적색, 청색, 검 정색과 같이 단색의 솔리드 색상(solid color)으로 나 눠진다. ${ }^{1,2}$ 피해자 의류 또는 사고 관련 차량에 부착 되는 페인트는 미량인 경우가 대부분으로 메탈릭이 나 펄 - 마이카 색상은 안료에 함유된 입자의 형상을 입체현미경 하에서 색상의 비교가 가능할 수 있으나 단색의 미량 페인트는 색상과 형상 비교에 있어 용이 하지 않을 때가 종종 있다. 따라서 본 연구의 목적은 차량의 차체와 범퍼에 적용되는 흰색, 노란색, 청색, 적색, 검정색의 단색 페인트에 대하여 micro-FT-IR과
micro-XRF를 이용하여 차량의 색상을 구현하는 베이 스코트 층의 바인더(binder)인 수지와 무기안료 (pigment)의 구성원소를 비교하여 페인트 동일성에 적용하고자 하였다. FT-IR은 4000 2000 $\mathrm{cm}^{-1}$ 영역에 서 특성 피크가 잘 나타나는 Reflectance 방법과 $2000 \sim 650 \mathrm{~cm}^{-1}$ 영역에서 재현성이 좋은 ATR 방법을 적용한 결과 시료의 색상 구분 없이 차체는 아크릴멜 라민 계통의 바인더 수지를, 범퍼는 아크릴우레탄 계 통의 바인더 수지를 주로 사용하였으며 1300 950 $\mathrm{cm}^{-1}$ 의 흡수대에서 바인더의 종류와 일부 유기안료에 따라 피크 패턴에 차이가 있으므로 페인트 동일성 비 교 시 이 영역에서 주의 깊은 해석이 요구되었다. $\mathrm{XRF}$ 분광기에 의하면 흰색 페인트는 $\mathrm{Ti}$, 노란색 페 인트는 $\mathrm{Si}$ 또는 $\mathrm{Bi}$, 적색 페인트는 $\mathrm{Ti}$ 또는 $\mathrm{Cl}$, 청색 과 검정색 페인트는 $\mathrm{Ti}$ 또는 $\mathrm{Ba}$ 가 주원소로 검출되 었으며 주원소 이외의 구성원소에는 다소 차이가 있 음을 알 수 있었고 XRF 분광법은 미량 페인트의 무 기안료에 함유된 구성원소를 확인하여 IR 스펙트럼 으로 동일성 비교가 곤란한 시료에 대해 판별 가능하 게 하였다.

\section{2. 시료 및 분석방법}

\section{1. 페인트 시료}

페인트 시료들은 2012년 'H'와 ' $\mathrm{K}$ ' 자동차사에서 생산되고 있는 차량 도장에 페인트를 공급하는 ' $\mathrm{K}$ ' 페인트사로부터 실제 차량에 적용되는 도장 공정과 동일한 조건으로 제작된 시편을 제공받아 실험하였 다. Table 1은 분석된 시료로서 basecoat 층에 알루미 늄, 펄 - 마이카 등 입자 형태의 effect pigment가 함유 되지 않은 단색의 흰색, 노란색, 적색, 청색 검정색 페인트의 색상명과 적용차량을 나타내었다. 차체는 $\mathrm{SBD}$ 로, 범퍼는 $\mathrm{SBP}$ 로 표기 하였으며, Creamy White 와 같이 색상 이름이 동일한 시료는 생산 공장 즉 차 종이 다른 경우 화학적 성분 차이가 있는지를 확인하 
Table 1. List of solid color paint samples

\begin{tabular}{|c|c|c|c|}
\hline \multicolumn{2}{|c|}{ Sample ID } & \multirow{2}{*}{$\begin{array}{c}\text { Color name } \\
\text { Creamy White }\end{array}$} & Model \\
\hline \multirow{16}{*}{ Body paint } & SBD-1 & & Santafe, New Santafe, Avante, i40, Veracruz \\
\hline & SBD-2 & Vanilla White & Santafe, New Santafe, Avante, i40, Veracruz \\
\hline & SBD-3 & Creamy White & Avante Hybrid, i30, New i30, New Avante \\
\hline & SBD-4 & Creamy White & Genesis coupe, Grand Starex, Tucson \\
\hline & SBD-5 & Creamy White & Porter \\
\hline & SBD-6 & Sun Flower & Accent, Veloster, Veloster turbo \\
\hline & SBD-7 & Dynamic Yellow & Genesis coupe, Grand Starex, Tucson \\
\hline & SBD-8 & Reddish Brown & Taxi(Sonata, Grandeur) \\
\hline & SBD-9 & Super Red & Genesis coupe, Grand Starex, Tucson \\
\hline & SBD-10 & Tropic Red & Avante Hybrid, i30, New i30, New Avante \\
\hline & SBD-11 & Alice Blue & Morning, Ray \\
\hline & SBD-12 & Onyx Blue & Porter \\
\hline & SBD-13 & Phantom Black & Santafe, New Santafe, Avante, i40, Veracruz \\
\hline & SBD-14 & Timeless Black & Genesis coupe, Grand Starex, Tucson \\
\hline & SBD-15 & Phantom Black & Tucson \\
\hline & SBD-16 & Black Diamond & Sonata, Sonata Hybrid, Grandeur \\
\hline \multirow{12}{*}{ Bumper paint } & SBP-1 & Creamy White & Genesis coupe, Grand Starex, Tucson \\
\hline & SBP-2 & Vanilla White & Santafe, New Santafe, Avante, i40, Veracruz \\
\hline & SBP-3 & Creamy White & Santafe, New Santafe, Avante, i40, Veracruz \\
\hline & SBP-4 & Sun Flower & Accent, Veloster, Veloster turbo \\
\hline & SBP-5 & Dynamic Yellow & Genesis coupe, Grand Starex, Tucson \\
\hline & SBP-6 & Reddish Brown & Taxi(Sonata, Grandeur) \\
\hline & SBP-7 & Super Red & Genesis coupe, Grand Starex, Tucson \\
\hline & SBP-8 & Onyx Blue & Porter \\
\hline & SBP-9 & Phantom Black & Accent, Veloster, Veloster turbo \\
\hline & SBP-10 & Phantom Black & Santafe, New Santafe, Avante, i40, Veracruz \\
\hline & SBP-11 & Phantom Black & Avante Hybrid, i30, New i30, New Avante \\
\hline & SBP-12 & Phantom Black & Tucson \\
\hline
\end{tabular}

기 위해 선택하였다.

\section{2. 분석방법}

\subsection{1. 시료채취}

입체현미경은 페인트 비교에 사용되는 기본 장비 로써 피해차량과 용의차량에 부착된 메탈릭과 펄 · 마 이카 등의 광택성 입자 형태를 비교할 수 있다. 그러 나 본 실험에서는 색상 층에 광택성 입자가 함유되지 않은 단색 페인트 시료로서 입체현미경으로는 동일 계통 색상의 시료에 대한 색상 구별이 곤란하였으며, basecoat의 안료 시료는 clearcoat나 surfacer가 혼입되 지 않고 실제 증거물로 제출되는 양 정도를 현미경 하에서 끝이 예리한 수술용 칼을 이용하여 페인트 시 편의 일부를 사선형태로 절단(bevel cutting)하여 분 석하였다.
2.2.2. Micro-FT-IR(Micro-Fourier Transform Infrared Spectrometer)

페인트 안료의 시료는 현미경 하에서 채취한 후 전 처리 없이 시료판(gold plate) 위에 놓고 롤러로 밀어 평편하게 한 후 $100 \mu \mathrm{m} \times 100 \mu \mathrm{m}$ 격자 크기로 Reflectance 방법과 ATR (attenuated total reflectance) 방법 2 가지로 분석하였다. Reflectance는 페인트 시료와 적외 선이 비접촉되어 측정되므로 시료의 평편성과 두께에 따라 피크의 패턴에 차이가 약간 있으나 ATR 방법은 게르마늄 크리스탈과 페인트 시료가 직접 접촉되므로 $2000-650 \mathrm{~cm}^{-1}$ 영역에서 피크의 재현성이 Reflectance 방법 보다 우수하여 피크의 해석이 용이하므로 동일 시 료에 대해 두 가지 방법을 이용하였다. 기기는 mercurycadmium-telluride (MCT) 검출기가 장착된 Nicolet iN10 (Thermo Scientific, USA)을 이용하여 분해능 $4 \mathrm{~cm}^{-1}$ 
로 측정하였으며 스펙트럼은 OMNIC 9.0 프로그램으 로 비교 해석하였다.

\subsubsection{Micro-XRF (Micro-X-ray Fluorescence Spec-} trometer)

페인트 basecoat 층의 안료에 존재하는 조성 원소를 확인하기 위하여 M4 Tornado (Bruker AXS GmbH, Germany)를 사용하였다. 시료는 예리한 칼과 핀셋을 이용해 양면 접착테이프에 붙여 시료 홀더에 놓고 분 석하였다. 측정은 $10 \mathrm{mbar}$ 이하의 진공상태에서 가속 전압 $30 \mathrm{kV}$, beam current $400 \mu \mathrm{A}$, collection time 500,000 Counts, energy range/gain 0-20 keV의 조건하 에서 실시하였다.

\section{3. 결과 및 고찰}

차량 페인트는 차체의 철 판재 또는 범퍼의 플라스 틱에 도장하기 위해 피도체와의 접착성, 내부식성, 외관성 및 내후성을 유지하기 위하여 Fig. 1과 같이 여러 개의 도막 층으로 구성되어 있다. 차량의 차체 도장은 일반적으로 전착도장(electrodeposited coat, ED coat), 서페이서(surfacer 또는 primer), basecoat, clearcoat의 도장 공정을 통해 이루에 지게 된다. 전착 도장은 epoxy를 약 $20 \mu \mathrm{m}$ 두께로 칠해 피도체인 철 판재에 방청효과를 주며, 서페이서는 polyester/

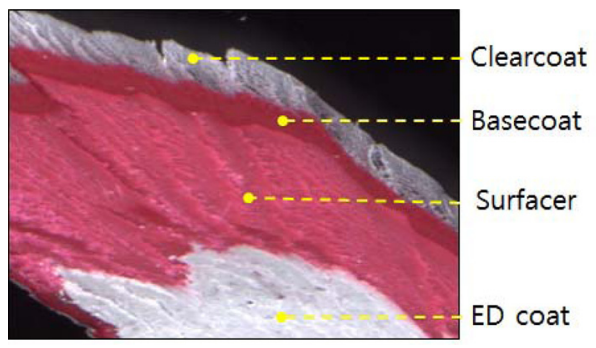

Fig. 1. A cross section of real layers obtained from an automotive red paint chip.

melamine을 30 40 $\mu \mathrm{m}$ 로 불투명성을 제공하여 은폐 효과를 부여하기 위해 두껍게 도장된다. basecoat는 acrylic melamine을 12 15 $\mu \mathrm{m}$ 로 안료에 의한 색상을 구현하는 도장이며 페인트의 표면 층에 안료가 함유 되지 않는 무색투명한 clearcoat는 acrylic melamine 을 30 45 $\mu \mathrm{m}$ 두께로 차량 페인트의 광택과 도장 시 스템을 보호한다. ${ }^{2}$ 본 연구는 페인트 구성 도막 층에 서 교통사고로 인해 차량 또는 의류 등에 부착될 수 있는 차량 색상을 구현하는 basecoat의 안료를 분석 비교 하였다.

\section{1. 흰색 페인트}

3.1.1. FT-IR에 의한 흰색 차체 안료의 비교

SBD-1 SBD-5 시료들은 Fig. 2에서 보는 바와 같이

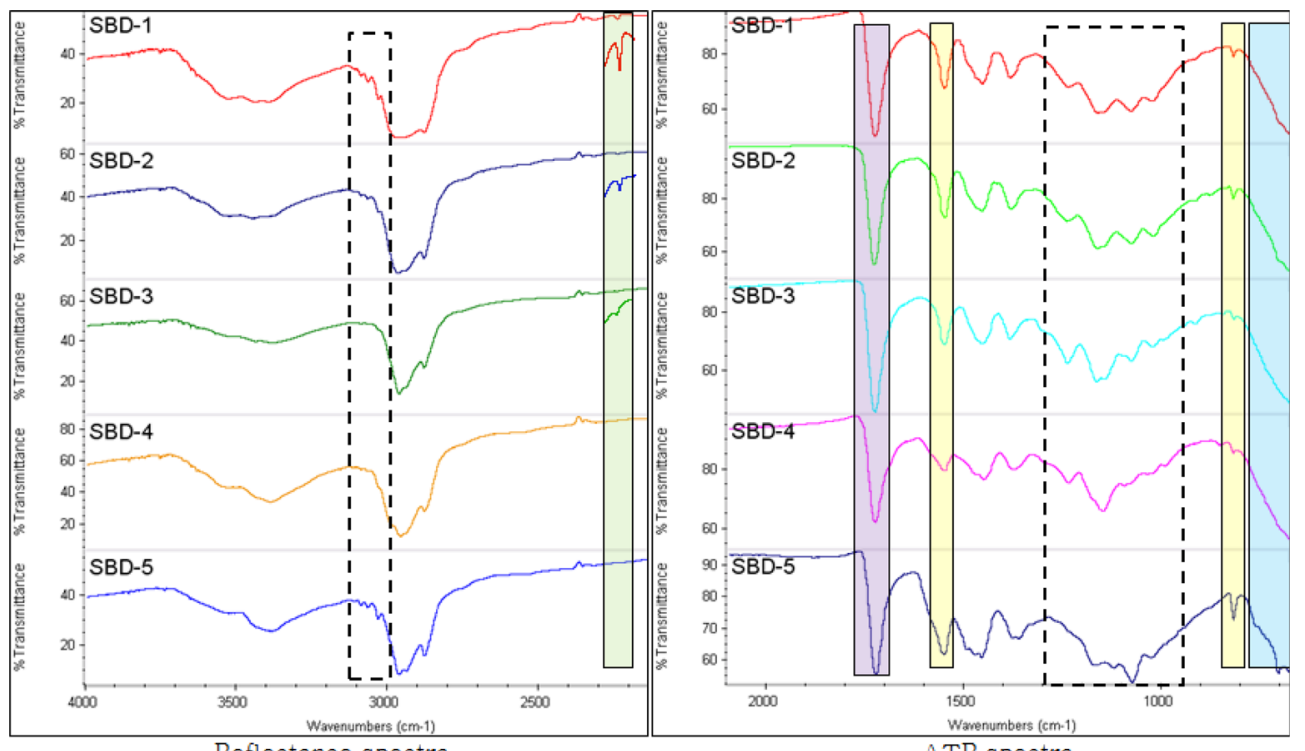

Fig. 2. FT-IR spectra of pigments in white body paint 
$1730 \mathrm{~cm}^{-1}$ 의 carbonyl, $1550 \mathrm{~cm}^{-1}$ 과 $815 \mathrm{~cm}^{-1}$ 의 melamine, $3100 \sim 3000 \mathrm{~cm}^{-1}$ 의 aromatics (styrene modification) 등에서 특성 피크가 보였으며, $800 \sim 650 \mathrm{~cm}^{-1}$ 에서 완 만한 흡수대는 흰색 안료에 주로 사용되는 $\mathrm{TiO}_{2}$ 가 함 유되었음을 알 수 있었다. ${ }^{3}$ 시료 모두는 $\mathrm{TiO}_{2}$ 의 특성 흡수와 함께 $702 \mathrm{~cm}^{-1}$ 에서 약한 styrene 피크가 공통적 으로 존재하였다. 이와 같은 스펙트럼은 아크릴(예, methylmethacrylate, acrylonitrile)과 melamine의 열경화 로 결합된 바인더임을 보여주는 것이다. ${ }^{45} \mathrm{SBD}-1$, SBD-2, SBD-3 시료의 스펙트럼에서는 $2233 \mathrm{~cm}^{-1}$ 부근 의 acrylonitrile $(-\mathrm{C}=\mathrm{N})$ 피크가 보이나 SBD-4와 SBD-5 시료에서는 보이지 않았다. 흰색 차체 페인트의 바인더 수지의 동일성 비교는 아크릴 수지의 종류에 따라 피 크 패턴에 차이를 보이는 $1300 \sim 950 \mathrm{~cm}^{-1}$ 영역 및 1730 $\mathrm{cm}^{-1}$ 의 carbonyl 피크와 $1550 \mathrm{~cm}^{-1}$ 의 melamine 피크의 상대적 피크의 비교로서 판단할 수 있었다.

\subsubsection{FT-R에 의한 흰색 범퍼 안료의 비교}

범퍼 페인트의 안료 분석은 차체에서 분석한 동일한 방법으로 무색투명한 클리어 층과 서페이서를 분리하 여 채취하였다. Fig. 3에서 보는 바와 같이 SBP1 SBP-3 시료들은 $3380 \mathrm{~cm}^{-1}$ 의 amide $(\mathrm{N}-\mathrm{H}), 1690 \mathrm{~cm}^{-1}$ 의 isocyanate $(\mathrm{C}=\mathrm{O}), 1530 \mathrm{~cm}^{-1}$ 의 carbamate $(\mathrm{N}-\mathrm{H})$, $800 \sim 650 \mathrm{~cm}^{-1}$ 의 $\mathrm{TiO}_{2}$ 에 의한 완만한 흡수가 공통적 으로 존재하였으며 이러한 특성 피크들은 차량 범퍼
의 basecoat 층에 아크릴우레탄계의 바인더가 사용됨을 알 수 있었다. SBP-1 시료는 aromatic ring의 3100 3000 $\mathrm{cm}^{-1}(\mathrm{C}-\mathrm{H})$ 와 $1494 \mathrm{~cm}^{-1}(\mathrm{C}=\mathrm{C})$ 피크가 $\mathrm{SBP}-2$ 및 $\mathrm{SBP}-$ 3 시료에 비해 강하게 나타났고 우레탄의 C-N-H와 $\mathrm{C}-\mathrm{O}$ carboxyl에 의한 $1250 \mathrm{~cm}^{-1}$ 및 acrylate $\mathrm{C}-\mathrm{O}$ 에 의 한 $1157 \mathrm{~cm}^{-1}$ 이 존재하는 $1300 \sim 960 \mathrm{~cm}^{-1}$ 영역에서 피 크 세기와 패턴이 다르게 나타났다. 범퍼에서 aromatic의 피크가 보이나 이는 우레탄계는 경화제인 isocyanate로 aliphatics이 사용되고 aromatics는 황변으 로 사용되지 않으므로 경화제에서 유래된 피크는 아 닌 것으로 보였다. ${ }^{6}$

\subsubsection{XRF에 의한 흰색 안료의 비교}

$\mathrm{XRF}$ 는 단일 층 또는 다중 도막 층의 페인트 시편

Table 2. Elemental composition of white pigment

\begin{tabular}{cccl}
\hline \hline & $\begin{array}{c}\text { Major } \\
(>80 \mathrm{wt} \%)\end{array}$ & $\begin{array}{c}\text { Minor } \\
(10 \sim 80 \mathrm{wt} \%)\end{array}$ & \multicolumn{1}{c}{$\begin{array}{c}\text { Trace } \\
(<10 \mathrm{wt} \%)\end{array}$} \\
\hline SBD-1 & $\mathrm{Ti}$ & $\mathrm{Si}$ & $\mathrm{Al}$ \\
SBD-2 & $\mathrm{Ti}$ & - & $\mathrm{Si}, \mathrm{Al}$ \\
SBD-3 & $\mathrm{Ti}$ & - & $\mathrm{Si}, \mathrm{Al}, \mathrm{Zr}$ \\
SBD-4 & $\mathrm{Ti}$ & - & $\mathrm{Al}, \mathrm{Si}, \mathrm{Zr}$ \\
SBD-5 & $\mathrm{Ti}$ & - & $\mathrm{S}, \mathrm{Si}, \mathrm{Al}$ \\
SBP-1 & $\mathrm{Ti}$ & - & $\mathrm{Al}, \mathrm{Si}, \mathrm{Fe}$ \\
SBP-2 & $\mathrm{Ti}$ & - & $\mathrm{S}, \mathrm{Cl}, \mathrm{Si}, \mathrm{Al}$ \\
SBP-3 & $\mathrm{Ti}$ & - & $\mathrm{Al}, \mathrm{Si}, \mathrm{Zr}$ \\
\hline
\end{tabular}

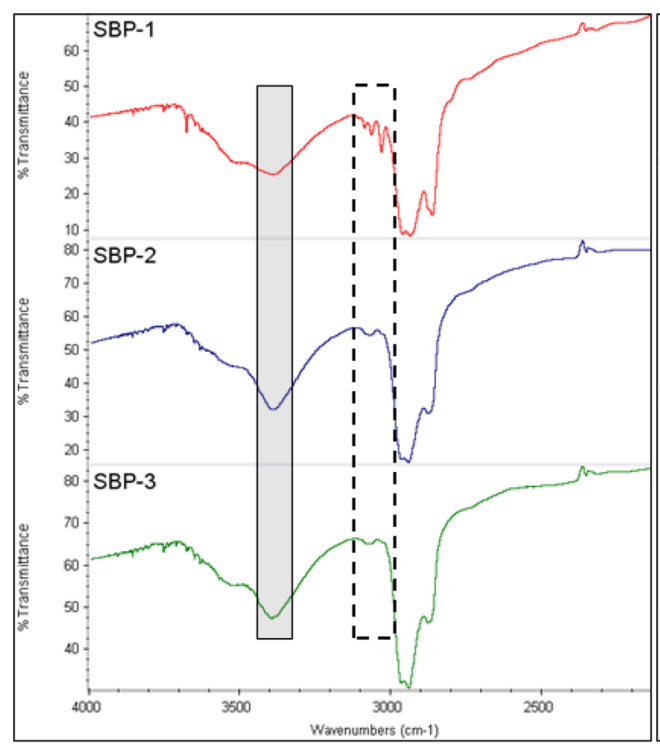

Reflectance spectra

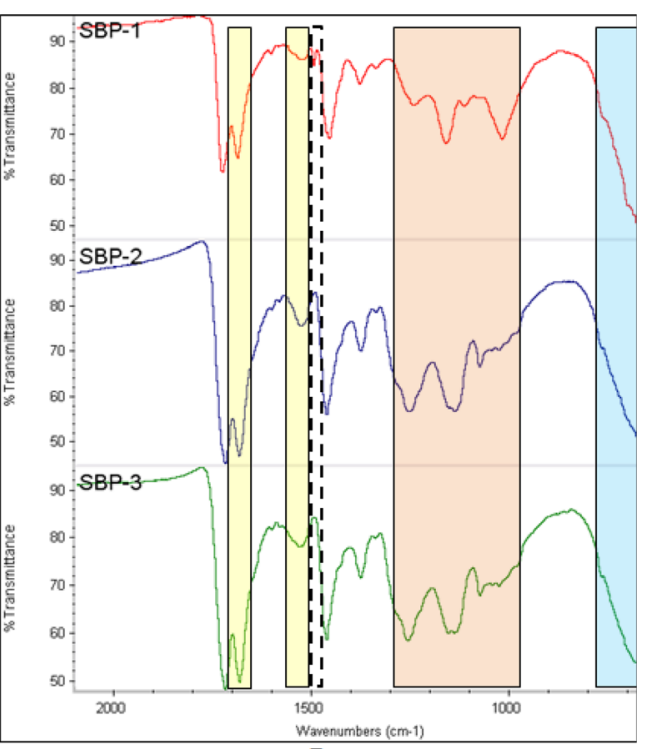

ATR spectra

Fig. 3. FT-IR spectra of pigments in white bumper paint. 
에 대해 여러 원소를 동시에 분석할 수 있다. Table 2 에서 보는 바와 같이 차량의 차체와 범퍼에 적용되는 흰색 basecoat에서는 주원소로 $\mathrm{Ti}$ 가 검출되었고 함유 된 구성 원소의 함량에 다소 차이를 보였다. Ti는 $\mathrm{TiO}_{2}$ (rutile) 형태로 불투명성과 내구성이 다른 안료에 비해 상당히 우수하여 차량에서 가장 일반적으로 사 용되는 흰색 안료이다. ${ }^{7} \mathrm{SBD}-1$ 은 다른 시료와 달리 비교적 $\mathrm{Si}$ 가 많이 검출되었으며, $\mathrm{SBD}-3, \mathrm{SBD}-4, \mathrm{SBP}-$ 3 시료에서는 $\mathrm{Zr}$ 이 미량 검출되었다. SBP-1시료에서 는 $\mathrm{Fe}$ 가 SBP-2에서는 다른 시료에서 검출되지 않은 $\mathrm{S}, \mathrm{Cl}$ 원소가 미량 검출되었다. XRF에 의한 법과학적 페인트의 안료 분석은 주원소와 부원소의 검출과 미 량으로 검출되는 원소의 존재 여부 및 전체적인 함량 비율을 고려하여 페인트 동일성 여부를 판단하여야 함을 알 수 있었다.

\section{2. 노란색 페인트}

3.2.1. FT- $\mathbb{R}$ 에 의한 노란색 안료의 비교

차체 시료인 SBD-6와 SBD-7, 범퍼 시료인 SBP-4 와 SBP-5의 IR 스펙트럼은 Fig. 4에 나타내었다. SBD-6와 SBD-7 시료는 흰색 차량의 차체에 적용되는 페인트와 유사한 아크릴 멜라민계로서 $1730 \mathrm{~cm}^{-1}$ 의 carbonyl, $1550 \mathrm{~cm}^{-1}$ 과 $815 \mathrm{~cm}^{-1}$ 의 멜라민 특성 피크 를 보였으며 1260 920 cm $\mathrm{cm}^{-1}$ 영역에서 시료들마다 피 크의 패턴이 약간씩 차이를 갖고 있음을 보였다. 또한
SBD-7 시료에서는 $2233 \mathrm{~cm}^{-1}$ 의 acrylonitrile 피크가 보이지 않았으나 SBD-6 시료에서는 약하게 보였으며, $800 \sim 650 \mathrm{~cm}^{-1}$ 영역에서 $\mathrm{SBD}-7$ 시료는 $\mathrm{TiO}_{2}$ 의 특성 흡수가 보이나 SBD-6 시료에서는 $\mathrm{TiO}_{2}$ 의 흡수 보다 는 styrene에 의한 $703 \mathrm{~cm}^{-1}$ 피크가 존재했다. SBP-4 와 SBP-5 시료는 우레탄계 바인더 수지로 $1690 \mathrm{~cm}^{-1}$ 의 isocyanate와 $1530 \mathrm{~cm}^{-1}$ 의 carbamate에 의한 피크가 공통적으로 보였다. SBP-4와 SBP-5 시료에서 $\mathrm{TiO}_{2}$ 의 특성 흡수가 보이고 SBP-5 시료는 다른 시료에서 보 이지 않는 $1787,1622,1418 \mathrm{~cm}^{-1}$ 피크가 보였으며 이 는 피크의 파수와 형상으로 보아 유기 안료(diarylide yellow pigment)에 의해 유래된 것으로 알 수 있었다. ${ }^{6}$

\subsubsection{XRF에 의한 노란색 안료의 비교}

차체 시료인 SBD-6은 IR 스펙트럼에서 다른 시료와 달리 $\mathrm{TiO}_{2}$ 특성 흡수가 나타나지 않았는데 XRF에서도 다른 시료에 비해 $\mathrm{Ti}$ 가 미량 검출되었고 $\mathrm{Si}$ 가 주원소로

Table 3. Elemental composition of yellow pigment

\begin{tabular}{cccl}
\hline & $\begin{array}{c}\text { Major } \\
(>35 \mathrm{wt} \%)\end{array}$ & $\begin{array}{c}\text { Minor } \\
(10 \sim 35 \mathrm{wt} \%)\end{array}$ & $\begin{array}{c}\text { Trace } \\
(<10 \mathrm{wt} \%)\end{array}$ \\
\hline SBD-6 & $\mathrm{Si}$ & $\mathrm{Bi}, \mathrm{V}$ & $\mathrm{Ti}, \mathrm{P}, \mathrm{Ca}$ \\
SBD-7 & $\mathrm{Bi}$ & $\mathrm{V}, \mathrm{Ti}$ & $\mathrm{Al}, \mathrm{Si}, \mathrm{P}, \mathrm{Ca}, \mathrm{Zn}$ \\
SBP-4 & $\mathrm{Bi}$ & $\mathrm{V}, \mathrm{Ti}$ & $\mathrm{Ca}, \mathrm{Zn}, \mathrm{P}, \mathrm{Al}, \mathrm{Si}$ \\
SBP-5 & $\mathrm{Bi}$ & $\mathrm{Ti}, \mathrm{V}$ & $\mathrm{Zn}, \mathrm{Ca}, \mathrm{Al}, \mathrm{P}, \mathrm{Si}$ \\
\hline
\end{tabular}

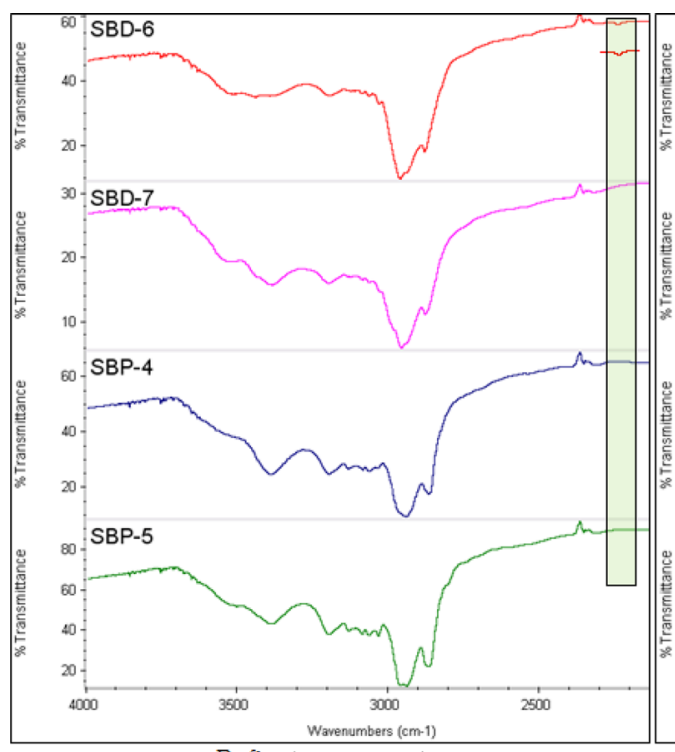

Reflectance spectra

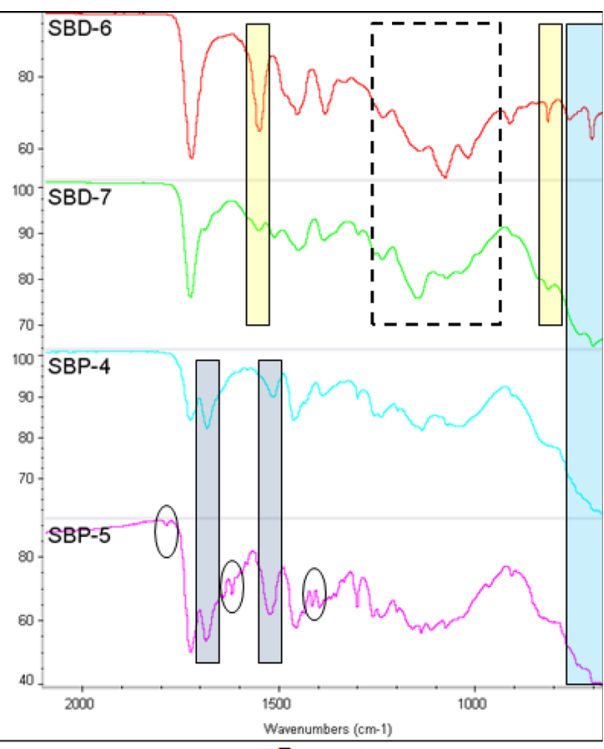

ATR spectra

Fig. 4. FT-IR spectra of pigments in yellow paint. 


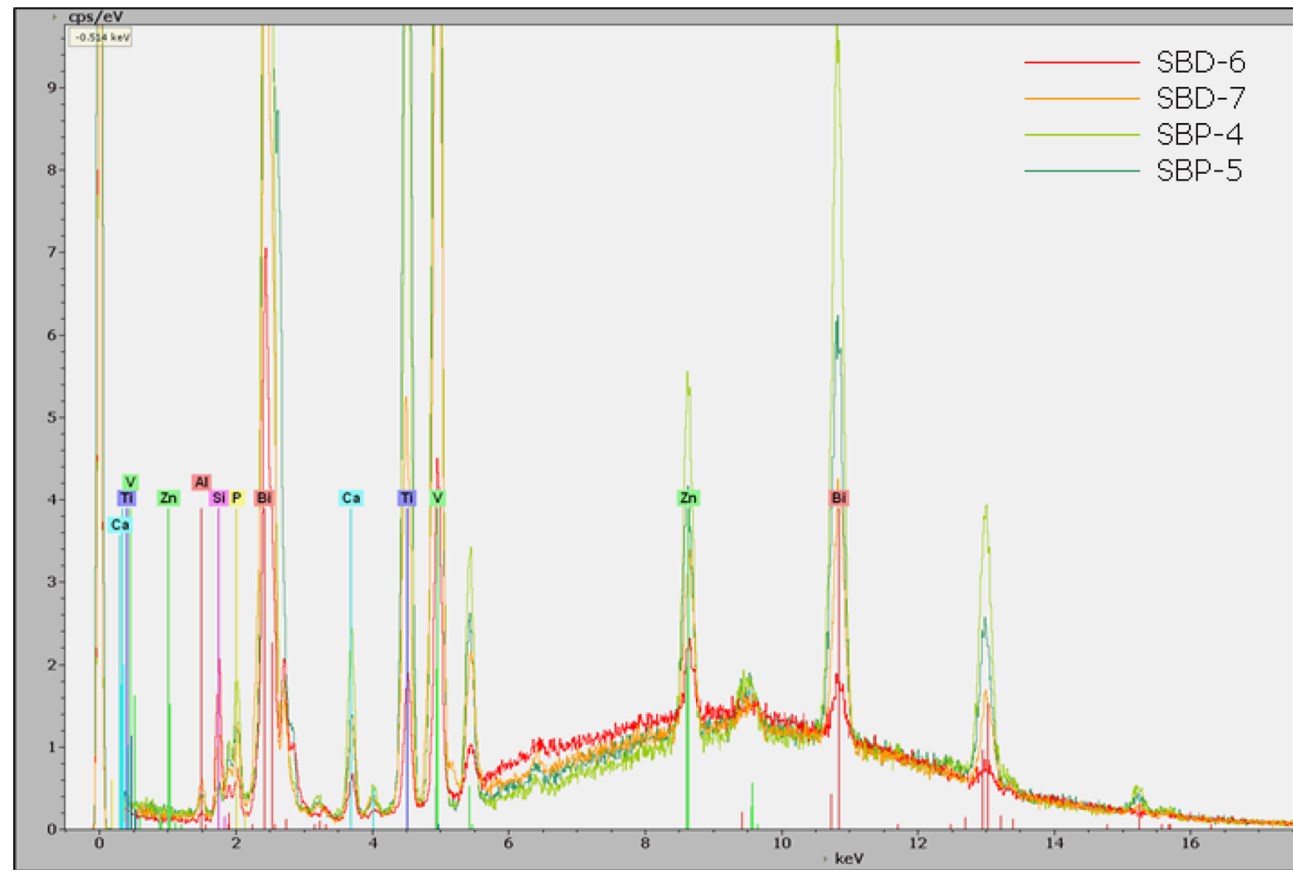

Fig. 5. XRF spectra of pigments in yellow paint.

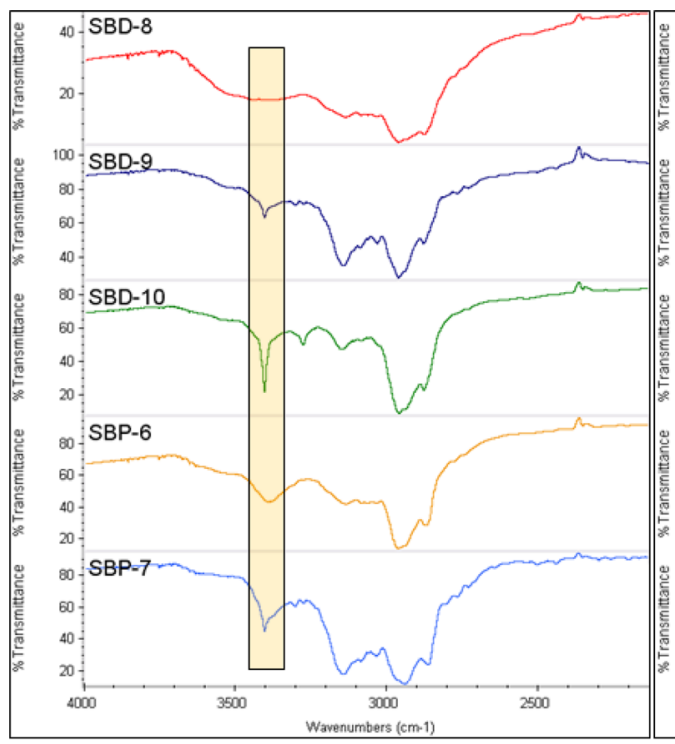

Reflectance spectra

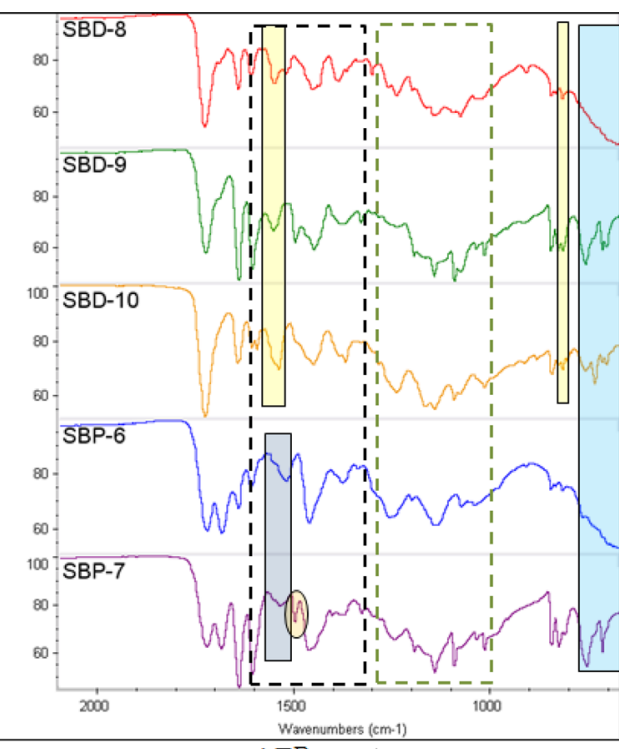

ATR spectra

Fig. 6. FT-IR spectra of pigments in red paint.

검출되었으며, Table 3과 Fig. 5는 노란색 페인트 안료의 $\mathrm{XRF}$ 에 의한 원소 조성을 나타내었다. SBD-7, SBP-4 및 $\mathrm{SBP}-5$ 시료들 간의 비교는 $\mathrm{Bi}$ 가 주원소로 공통적으로 검출되었으나 부원소인 $\mathrm{Ti}$ 와 $\mathrm{V}$, 미량 원소인 $\mathrm{Al}, \mathrm{Si}, \mathrm{P}$, $\mathrm{Ca}, \mathrm{Zn}$ 가 상대적 함량 차이를 보였다. 노란색 안료 시료
에서 검출되는 $\mathrm{Bi}$ 는 $\mathrm{Pb}$ 대신에 사용되는 안료이다.

\section{3. 적색 페인트}

3.3.1. FT- $\mathbb{R}$ 에 의한 적색 안료의 비교

SBD-8 시료는 서울 택시에 적용되는 꽃담황토색으 
Table 4. Elemental composition of red pigment

\begin{tabular}{lccl}
\hline \hline & $\begin{array}{c}\text { Major } \\
(>40 w t \%)\end{array}$ & $\begin{array}{c}\text { Minor } \\
(10 \sim 40 w t \%)\end{array}$ & \multicolumn{1}{c}{$\begin{array}{c}\text { Trace } \\
(<10 w t \%)\end{array}$} \\
\hline SBD8 & $\mathrm{Ti}$ & $\mathrm{Bi}, \mathrm{V}$ & $\mathrm{P}, \mathrm{Al}, \mathrm{Zn}, \mathrm{Si}, \mathrm{Ca}$ \\
SBD9 & $\mathrm{Cl}$ & $\mathrm{Ba}, \mathrm{S}$ & $\mathrm{Si}, \mathrm{Al}$ \\
SBD10 & $\mathrm{Cl}$ & $\mathrm{Si}$ & $\mathrm{S}$ \\
SBP6 & $\mathrm{Ti}$ & $\mathrm{Bi}$ & $\mathrm{V}, \mathrm{P}, \mathrm{Ca}, \mathrm{Al}, \mathrm{Zn}, \mathrm{Fe}$ \\
SBP7 & $\mathrm{Cl}$ & $\mathrm{Ba}$ & $\mathrm{S}, \mathrm{Si}$ \\
\hline
\end{tabular}

로 $\mathrm{SBD}-9$ 와 SBD-10 시료에 비해 연한 색상의 적색 으로 $\mathrm{TiO}_{2}$ 의 특성 흡수를 나타내었다. Fig. 6에서 보 는 바와 같이 차체의 SBD-8, SBD-9 및 SBD-10 시료 는 흰색과 노란색의 안료 수지와 마찬가지로 아크릴 멜라민의 특성 피크를 공통적으로 보였으나 SBD-9와 SBD-10 시료는 $3400 \mathrm{~cm}^{-1}$ 의 예리한 N-H (primary amide free) 피크가 보였으나 SBD-8 시료에서는 피크가 보이 지 않았다. 또한 각 시료들은 $1300 ~ 1000 \mathrm{~cm}^{-1}$ 영역에 서 피크의 세기와 패턴의 차이가 있었다. 범퍼의 SBP-6, SBP-7 시료는 아크릴우레탄 특성 피크를 공통 적으로 보였으나 SBP-6 시료와는 달리 SBP-7 시료에 서는 $3400 \mathrm{~cm}^{-1}$ 의 N-H(primary amide free)와 1495 $\mathrm{cm}^{-1}$ 의 (unsaturated $\mathrm{C}=\mathrm{C}$ ) 피크를 보였으며, 1610 1320 $\mathrm{cm}^{-1}$ 과 845 650 $\mathrm{cm}^{-1}$ 영역에서 피크의 패턴이 달랐다. $\mathrm{SBD}-8$ 시료와 SBP-6 시료는 각각 차체와 범퍼에 적 용되는 동일 색상의 페인트로 다른 시료에 비해 색상
이 연한 적색으로 공히 $\mathrm{TiO}_{2}$ 가 함유되어 있음을 알 수 있었다.

\subsubsection{XRF에 의한 적색 안료의 비교}

$\mathrm{SBD}-8$ 과 SBP-6는 동일 색상으로 IR 스펙트럼에서 $\mathrm{TiO}_{2}$ 의 특성이 나타났고 XRF에서도 주원소로 $\mathrm{Ti}$ 가 검출되었다. Table 4에서 보는 바와 같이 SBD-9, $\mathrm{SBD}-10, \mathrm{SBP}-7$ 시료의 주성분은 $\mathrm{Cl}$ 이 검출되었으나 ${ }^{8}$ 부원소와 미량 원소의 $\mathrm{Ba}, \mathrm{Bi}, \mathrm{S}, \mathrm{Si}$ 등 검출되는 원소 들이 상이하였다.

\section{4. 청색 페인트}

3.4.1. FT- $\mathbb{R}$ 에 의한 청색 안료의 비교

SBD-11 시료는 연청색이고 SBD-12와 SBP-8은 진 청색(Onyx blue)의 동일 색상으로 색상에 약간 차이 가 있는 시료이다. Fig. 7에서 보는 바와 같이 차체에 적용되는 수지는 아크릴 멜라민 특성 피크가 있으며, 범퍼는 아크릴우레탄 수지가 사용됨을 알 수 있었다. 동일 색상인 차체의 SBD- 12 와 범퍼의 SBP-8 시료는 $\mathrm{SBD}-11$ 에 비해 $3109 \sim 3014 \mathrm{~cm}^{-1}$ 와 $700 \mathrm{~cm}^{-1}$ 부근에서 aromatics의 특성 피크가 나타났으나 $1300 ~ 1045 \mathrm{~cm}^{-1}$ 에서 아크릴 성분이 다른 스펙트럼 양상을 보였다. ${ }^{9}$

3.4.2. XRF에 의한 청색 안료의 비교

청색 차체 SBP-11 시료는 $\mathrm{TiO}_{2}$ 의 특성 흡수를 보였

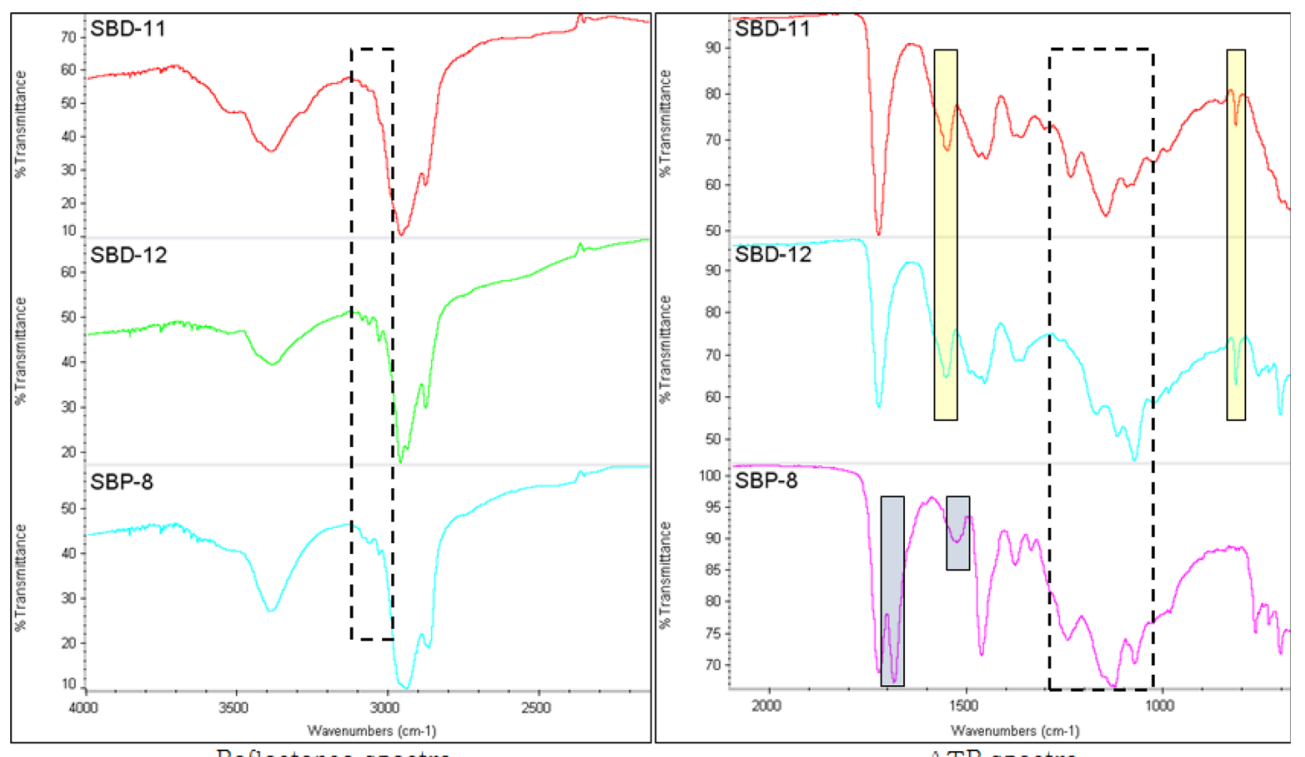

Reflectance spectra

ATR spectra

Fig. 7. FT-IR spectra of pigments in blue paint. 
Table 5. Elemental composition of blue pigment

\begin{tabular}{lccl}
\hline \hline & $\begin{array}{c}\text { Major } \\
(>40 \mathrm{wt} \%)\end{array}$ & $\begin{array}{c}\text { Minor } \\
(10 \sim 40 \mathrm{wt} \%)\end{array}$ & $\begin{array}{l}\text { Trace } \\
(<10 \mathrm{wt} \%)\end{array}$ \\
\hline SBD-11 & $\mathrm{Ti}$ & - & $\mathrm{Al}, \mathrm{Si}, \mathrm{Ca}, \mathrm{Zr}$ \\
SBD-12 & $\mathrm{Ba}$ & $\mathrm{Ti}$ & $\mathrm{Si}, \mathrm{Al}$ \\
SBP-8 & $\mathrm{Ti}$ & $\mathrm{Ba}, \mathrm{Si}, \mathrm{S}$ & $\mathrm{Cu}, \mathrm{Al}$ \\
\hline
\end{tabular}

으며 Table 5에서 보는 바와 같이 XRF에서도 $\mathrm{Ti}$ 가 주 원소로 검출되었다. SBD-12와 SBP-8 시료는 동일 색 상(Onyx blue)이지만 SBD-12 시료는 주원소로 $\mathrm{Ba}$ 이 검출되었고 SBP-8 시료는 Ti가 주원소로 검출되었으 며 검출된 부원소와 미량 원소가 달랐다. 이는 육안으 로 동일 색상으로 보일지라도 페인트 동일성을 판별 하기 위해서는 IR과 XRF로 분석할 필요가 있음을 보 여준다.

\section{5. 검정색 페인트}

3.5.1. FT-R에 의한 검정색 차체 안료의 비교

SBD-13, SBD-14, SBD-15, SBD-16 시료들은 차체 에 사용되는 아크릴멜라민 수지의 특성 피크가 Fig. 8 에서 보는 바와 같이 공통적으로 나타났으나 SBD-14 시료는 SBD-13, SBD-15, SBD-16 시료들에서 보이는 $2233 \mathrm{~cm}^{-1}$ 부근의 acrylonitrile $(-\mathrm{C}=\mathrm{N})$ 피크가 보이지 않았다. 또한 SBD-14, SBD-16 시료는 acrylate ester (C-O)의 1218 953 $\mathrm{cm}^{-1}$ 영역에서 SBD-13 및 SBD-15
시료와 피크 패턴이 상이하였다. 각 시료들은 1720 $\mathrm{cm}^{-1}$ 의 $\mathrm{C}=\mathrm{O}$ carbonyl 피크와 $1550 \mathrm{~cm}^{-1}$ 의 melamine (triazine ring) 피크의 상대적 비교로 시료간의 melamine 함량 차이를 판별할 수 있었다. ${ }^{10,11}$ 페인트 동일성 비교에 대해 판단할 때는 스펙트럼에서 재현 성 있는 미약한 피크, 피크의 세기와 패턴 및 carbonyl 피크와 $1550 \mathrm{~cm}^{-1}$ 의 melamine 피크와 같은 피크의 상 대적 세기를 비교하여 해석할 필요가 있다.

3.5.2. FT-R에 의한 검정색 범퍼 안료의 비교

SBP-9, SBP-10, SBP-11, SBP-12 시료들은 아크릴 우레탄 수지의 특성 피크를 보였으며, 공히 Phantom Black의 동일 색상으로 ' $\mathrm{K}$ ' 페인트사에서 제공되는 색 상 코드가 다르고 페인트가 적용되는 자동차 생산 공 장라인이 다른 시료들이었다. Fig. 9 스펙트럼에서 보 는 바와 같이 SBP-10은 $1270 ~ 950 \mathrm{~cm}^{-1}$ 영역에서 다 른 시료와 피크의 패턴 차이가 있었으나 SBP-9, SBP$11, \mathrm{SBP}-12$ 시료들 간의 IR 스펙트럼으로는 피크의 차이를 판별할 수 없으므로 XRF에 의한 무기안료의 원소 확인으로 페인트 동일성을 판별할 필요가 있었 다.

\subsubsection{XRF에 의한 검정색 안료의 비교}

차체 페인트 SBD-13과 SBD-14 시료들은 주원소로 $\mathrm{Ba}, \mathrm{SBD}-15$ 시료는 주원소로 $\mathrm{Ti}, \mathrm{SBD}-16$ 시료는 주

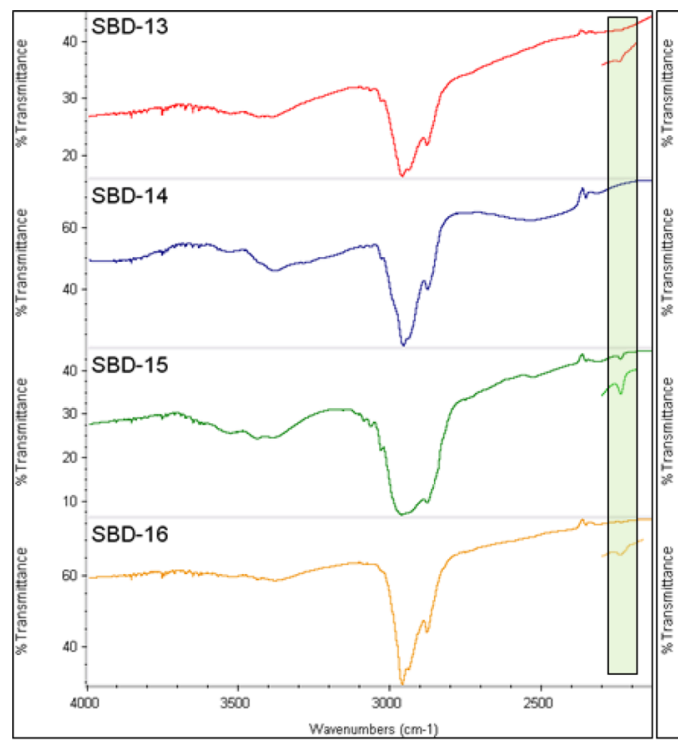

Reflectance spectra

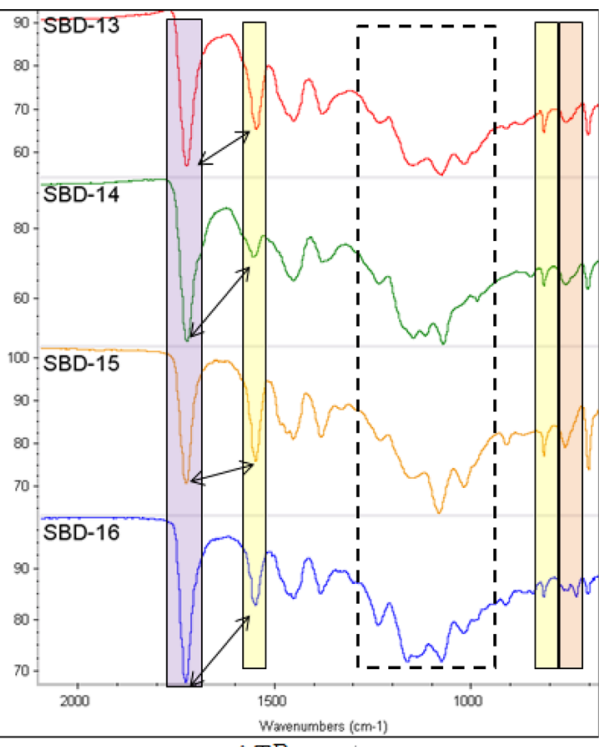

ATR spectra

Fig. 8. FT-IR spectra of pigments in black body paint. 


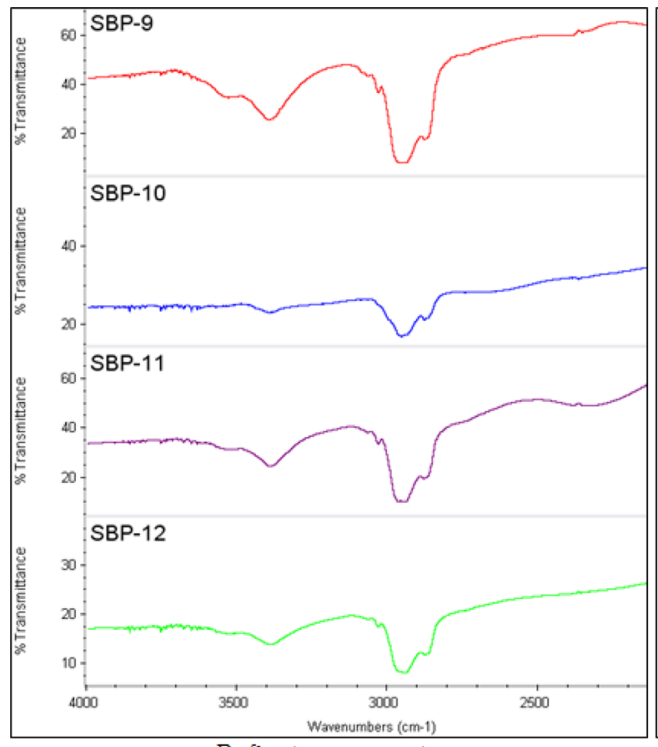

Reflectance spectra

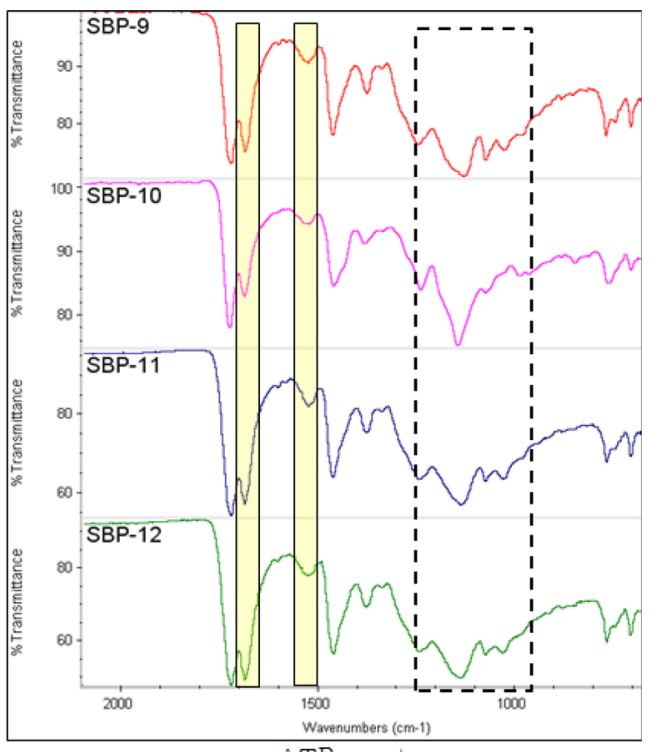

ATR spectra

Fig. 9. FT-IR spectra of pigments in black bumper paint.

Table 6. Elemental composition of black pigment

\begin{tabular}{llll}
\hline \hline & $\begin{array}{c}\text { Major } \\
(>30 \mathrm{wt} \%)\end{array}$ & $\begin{array}{c}\text { Minor } \\
(10 \sim 35 \mathrm{wt} \%)\end{array}$ & $\begin{array}{l}\text { Trace } \\
(<10 \mathrm{wt} \%)\end{array}$ \\
\hline SBD-13 & $\mathrm{Ba}$ & $\mathrm{S}, \mathrm{Si}$ & $\mathrm{Al}, \mathrm{Ti}$ \\
SBD-14 & $\mathrm{Ba}$ & $\mathrm{S}$ & $\mathrm{Al}, \mathrm{Si}, \mathrm{Ti}$ \\
SBD-15 & $\mathrm{Ti}$ & $\mathrm{Ba}, \mathrm{S}$ & $\mathrm{Fe}, \mathrm{Al}, \mathrm{Si}$ \\
SBD-16 & $\mathrm{Ba}, \mathrm{Si}, \mathrm{S}$ & - & $\mathrm{Ti}$ \\
SBP-9 & $\mathrm{Ba}$ & $\mathrm{S}, \mathrm{Si}, \mathrm{Ca}$ & - \\
SBP-10 & $\mathrm{Ba}$ & $\mathrm{Ca}$ & $\mathrm{Si}$ \\
SBP-11 & $\mathrm{Si}$ & $\mathrm{Ca}, \mathrm{Ti}$ & $\mathrm{Ba}$ \\
SBP-12 & $\mathrm{Si}$ & $\mathrm{Ca}$ & $\mathrm{Ti}$ \\
\hline
\end{tabular}

원소로 $\mathrm{Ba}, \mathrm{Si}, \mathrm{S}$ 가 각각 검출되어 시료들 간의 안료 비교가 가능하였다(Table 6). 범퍼 시료인 SBP-9, SBP-11, SBP-12 시료들은 IR 스펙트럼으로 페인트의 동일성에 대한 판별이 곤란했으나 SBP-9 시료는 주원 소로 $\mathrm{Ba}$ 이 검출되었으나 $\mathrm{SBP}-11$ 과 $\mathrm{SBP}-12$ 시료는 $\mathrm{Si}$ 가 주원소로 검출되었으며 SBP-11과 SBP-12 시료 간 에는 검출된 부원소와 미량 원소가 상이하였다. 따라 서 IR 스펙트럼에서 판별하기 어려운 안료는 XRF에 의해 구성 원소를 확인할 필요가 있었다.

\section{4. 결 론}

교통사고에서 차량과 의류에 부착되는 미량의 단색
페인트에 대한 안료의 분석 목적은 바인더 수지의 성 분과 무기안료의 함유 원소를 확인하여 동일성 여부 를 판별하고자 하였다. 차체 안료의 바인더는 아크릴 멜라민 계통의 수지이고 범퍼 안료의 바인더는 아크 릴우레탄 계통의 수지로서 각 시료마다 특이 피크와 패턴을 확인하였고 XRF를 이용한 무기안료의 구성 원소가 다소 차이를 보였으며 다음과 같은 결론을 얻 었다.

1. 흰색 페인트:FT-IR에 의한 안료 수지는 styrene modified acrylic melamine계통으로 확인되었다. 5 개의 시료 중에서 3 개 시료에서 $2233 \mathrm{~cm}^{-1}$ 의 acrylonitrile 피크를 보이는 특성이 있었고 시료들은 $1730 \mathrm{~cm}^{-1}$ 의 carbonyl 피크와 $1550 \mathrm{~cm}^{-1}$ 의 melamine 피크의 상대 적 세기 및 $1300 \sim 950 \mathrm{~cm}^{-1}$ 영역에서의 피크 패턴이 다소 상이함을 보였다. 범퍼 페인트 3 개의 시료 중 1 개 의 시료에서 $3100 \sim 3000 \mathrm{~cm}^{-1}$ 영역에서 aromatic ring의 $\mathrm{C}-\mathrm{H}$ 와 $1494 \mathrm{~cm}^{-1}$ 의 $\mathrm{C}=\mathrm{C}$ 피크가 강하게 나타났다. IR 스펙트럼에서 $\mathrm{TiO}_{2}$ 의 특성에 의한 $800 \sim 650 \mathrm{~cm}^{-1}$ 영역 의 완만한 흡수를 보이는 시료는 XRF에서 $\mathrm{Ti}$ 가 주원 소로 검출되었다. 각 시료들은 검출된 주원소와 미량 원소의 확인으로 안료의 판별이 가능하였다.

2. 노란색 페인트:FT-IR에 의한 안료의 분석에서는 시료 2 개 중 1 개의 시료에서 acrylonitrile 피크가 존재 하고 melamine 피크가 상대적으로 강하게 나타나서 안료의 구분이 가능 하였으며 범퍼 안료의 수지는 
isocyanate의 $\mathrm{C}=\mathrm{O}$ 에 의한 $1690 \mathrm{~cm}^{-1}$ 과 carbamate의 $\mathrm{N}-\mathrm{H}$ 에 의한 $1530 \mathrm{~cm}^{-1}$ 피크의 세기가 상대적으로 차 이가 있었다. XRF에서는 차체와 범퍼의 주원소로 4 개 시료 중 1 개를 제외하고 $\mathrm{Bi}$ 가 주원소로 검출되었 고 1 개의 시료에서는 주원소로 $\mathrm{Si}$ 가 검출되어 노란색 페인트 안료의 구분이 가능하였다.

3. 적색 페인트:FT-IR에 의한 차체의 5 개 시료 중에 서 1 개의 시료에서만 $3400 \mathrm{~cm}^{-1}$ 의 강한 N-H (primary amide free) 피크가 보이지 않았고 나머지 4 개의 시료에 서는 피크가 보였다. 각 시료의 스펙트럼은 1300 1000 $\mathrm{cm}^{-1}$ 의 영역에서 피크의 세기와 패턴에 차이가 있었 다. XRF에서 적색의 차체와 범퍼 안료에서 $\mathrm{Ti}$ 와 $\mathrm{Cl}$ 이 주원소로 검출되었으며, 각 시료들은 $\mathrm{Bi}, \mathrm{V}, \mathrm{Ba}, \mathrm{Si}, \mathrm{S}$ 등의 구성 원소에 다소 차이를 보였다.

4. 청색 페인트:FT-IR에 의한 차체 시료는 3109 3014 $\mathrm{cm}^{-1}$ 와 $700 \mathrm{~cm}^{-1}$ 부근의 aromatics의 특성 피크와 $1300 ~ 1045 \mathrm{~cm}^{-1}$ 영역에서 상이한 스펙트럼 패턴을 보 였으며 차체와 범퍼에 적용되는 동일한 색상의 시료 는 IR 스펙트럼에서 구별이 가능하였고 XRF에서도 주원소인 $\mathrm{Ti}, \mathrm{Ba}$, 부원소인 $\mathrm{Ba}, \mathrm{Si}$ 등 구성 원소가 다 소 차이점을 보였다.

5. 검정색 페인트:FT-IR에 의한 차체 시료에서 2233 $\mathrm{cm}^{-1}$ 부근의 acrylonitrile $(-\mathrm{C}=\mathrm{N})$ 피크가 보이는 안료가 있었고 각 시료들은 $1720 \mathrm{~cm}^{-1}$ 의 $\mathrm{C}=\mathrm{O}$ carbonyl 피크와 $1550 \mathrm{~cm}^{-1}$ 의 melamine (triazine ring) 피크의 상대적 비교로 시료간의 melamine 함량 차이를 비교할 수 있 었다. XRF에 의한 범퍼는 색상이 동일한 페인트의 IR 스펙트럼은 유사한 피크의 패턴을 보였으나 검출 된 주원소인 $\mathrm{Ba}, \mathrm{Si}$, 부원소인 $\mathrm{Ca}$, 미량 원소인 $\mathrm{Ti}$ 가 다소 차이가 있음을 보였다.

Micro-FT-IR에 의한 분석은 차량 페인트의 basecoat 층의 안료에 대한 법과학적 동일성 비교에 상당히 유 용한 기법이었다. IR 분석은 Reflectance와 ATR 2가 지 방법의 병용은 판별에 유용하였으며 XRF에 의한 분석은 미량 페인트의 무기안료의 원소 조성을 확인 하는데 효과적이었다.

\section{감사의 글}

이 논문은 2012년도 미래창조과학부 R\&D 프로그 램의 범죄증거물의 유효화를 위한 분자감지기술개발 사업(2012-009832) 재원으로 수행한 연구이며 이에 감사드립니다.

\section{참고문헌}

1. B. Caddy, 'Forensic Examination of Glass and Paint', 2rd ED., Taylor \& Francis Press, 2001.

2. H. Yari, S. Moradian, B. Ramezanzadeh, A. Kashani and M. Niknahad, Progress in Organic Coatings, 75, 420-428 (2012).

3. E. M. Suzuki, 'Interpretation of Automotive paint Infrared spectra', AFSN $3^{\text {rd }}$ Annual Meeting \& Symposium (2011).

4. E. M. Suzuki and W. P. Marshall, J. Forensic Sci., 41, 393-406 (1996).

5. E. M. Suzuki and W. P. Marshall, J. Forensic Sci., 44, 297-313 (1999).

6. D. G. Weldon, 'Failure Analysis of Paints and Coatings', 48-96, Wiley, 2009

7. Z. P. Janina and R. Borusiewicz, J. Molecular Structure, 792-793, 286-292 (2005).

8. F. Govaert and M. Bernard, Foresic Science International, 140, 61-70 (2004).

9. M. Szafarska, M. Wozniakiewicz, M. Pilch, Z. P. Janina and P. Koscielniak, J. Molecular Structure, 924926, 504-513 (2009).

10. G. Massonnet and W. Stoecklein, Science \& Justice, 39(2), 135-140 (1999).

11. Y. Nishiwaki, S. Watanabe and O. Shimoda, J. Forensic Science, 54(3), 564-570 (2009). 